\title{
Absence of a Persistently Elevated 37 kDa Fos-Related Antigen and AP-1-Like DNA-Binding Activity in the Brains of Kainic Acid- Treated fosB Null Mice
}

\author{
Allan Mandelzys, ${ }^{1}$ Mary Ann Gruda, ${ }^{2}$ Rodrigo Bravo, ${ }^{2}$ and James I. Morgan ${ }^{1}$ \\ ${ }^{1}$ Department of Developmental Neurobiology, St. Jude Children's Research Hospital, Memphis, Tennessee 38105, and \\ 2Department of Oncology, Bristol Myers-Squibb Pharmaceutical Research Institute, Princeton, New Jersey 08543-4000
}

Chronic stimulation of the nervous system or acute administration of kainic acid results in a persistent increase in AP-1-like DNA-binding activity in the brain. However, the composition and function of these AP-1 complexes remain controversial. By comparing wild-type and fosB-null mice treated with kainic acid, we establish that the complexes comprise JunD in association with an $\sim 37 \mathrm{kDa} \Delta$-FosB species. $\Delta$-FosB was expressed persistently in neurons in many areas of the CNS, even though fosB mRNA only increased transiently. This implies that the $37 \mathrm{kDa}$ protein is very stable. fos $\mathrm{B}-/-$ mice are predisposed to seizures. Therefore, the chronic expression of $\Delta$-FosB elicited by kainic acid seizures may be indicative of a compensatory/protective role in the pathophysiology of epilepsy.

Key words: $\Delta$-FosB; JunD; chronic Fra; epileptogenesis; protein stability; neurons
Stimulation of the nervous system by diverse means leads to the rapid and transient induction of cellular immediate early genes (cIEG) such as c-fos and c-jun (for review, see Sheng and Greenberg, 1990; Morgan and Curran, 1991a). Fos and Jun, as well as additional members of the Fos and Jun families, can participate in homo- and heterodimeric complexes that constitute the transcription factor activity, called activator protein-1 (AP-1) (for review, see Curran and Franza, 1988). These properties have lead to the proposal that some cIEGs represent components of a stimulustranscription coupling cascade that links brief periods of activation to more persistent alterations in neuronal phenotype by modifying target gene expression (Curran and Morgan, 1987).

Although many studies have shown the transient nature of the cIEG response in the brain, it is becoming apparent that individual members of the cIEG class can have distinctive temporal patterns of expression (Morgan and Curran, 1991a). For example, c-jun is persistently induced in axotomized spinal cord motor neurons (Jenkins and Hunt, 1991; Herdegen et al., 1992). However, one of the most dramatic and atypical patterns of cIEG expression is observed after application of certain chronic stimuli to the nervous system (for review, Pennypacker et al., 1995).

Repetitive electroconvulsive seizures, chronic treatment with certain drugs of abuse or induction of status epilepticus with kainic acid lead to a persistent increase in AP-1-like DNAbinding activity in the brain (Hope et al., 1992, 1994a,b; Pennypacker et al., 1994; Kasof et al., 1995). Moreover, based upon supershift and immunoblot analyses, these AP-1 complexes appear to be heterodimers of JunD in association with a series of

\footnotetext{
Received March 6, 1997; revised April 23, 1997; accepted May 1, 1997.

This work was supported in part by National Institutes of Health Cancer Center Support CORE Grant P30 CA21765 and by the American Lebanese Syrian Associated Charities.

Correspondence should be addressed to Dr. James Morgan, Department of Developmental Neurobiology, St. Jude Children's Research Hospital, 332 N. Lauderdale, Memphis, TN 38105.

Dr. Mandelzys's present address: Allelix Bio-Pharmaceuticals, 6850 Goreway Drive, Mississauga, Ontario, Canada L4V 1 V7.

Copyright (C) 1997 Society for Neuroscience $\quad 0270-6474 / 97 / 175407-09 \$ 05.00 / 0$
}

proteins in the range of 35-37 kDa that cross-react with antisera to FosB (Hope et al., 1994b; Chen et al., 1995). While these proteins have physical and immunological properties consistent with the splice variant of FosB, termed $\Delta$-FosB (Dobrzanski et al., 1991; Mumberg et al., 1991; Nakabeppu and Nathans, 1991; Yen et al., 1991), their precise identity remains uncertain. Some of this ambiguity stems from the fact that while fos B mRNA is induced during the acute response to a stimulus, it is not chronically elevated (Chen et al., 1995; Kasof et al., 1995). One means of determining the molecular identity of the $\Delta$-FosB-like material and assessing its possible physiological significance is through the analysis of fosB-null mice.

Recently, two laboratories described the generation of independent lines of mice that lack a functional fos $\mathrm{B}$ gene (Brown et al., 1996; Gruda et al., 1996). Both lines have grossly normal nervous systems. One of the lines is characterized by deficits in maternal behavior (Brown et al., 1996). The other line is normal in this regards but the mice have a predisposition to developing spontaneous and evoked tonic-clonic seizures (Gruda et al., 1996; M. Gruda, unpublished observations). The latter strain of fos Bnull mice were analyzed further. We establish here that the chronically elevated AP-1-like DNA-binding activity and FosBlike immunoreactivity (FBLI) is absent in fos B-null mice treated with kainic acid. The implications of these results to epileptogenesis are discussed.

\section{MATERIALS AND METHODS}

Animals and treatments. Young adult male rats (200-300 gm, Sprague Dawley, CD strain) were obtained from Charles River (Wilmington,

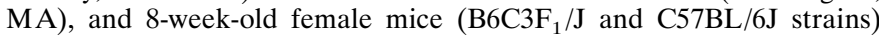
were obtained from Jackson Laboratories (Bar Harbor, ME). The fos $\mathrm{B}-/-$ mice were generated by injecting D3 (129Sv+/+, XY karyotype) embryonic stem cells into $\mathrm{C} 57 \mathrm{BL} / 6 \mathrm{~J}$ blastocysts, as described (Gruda et al., 1996). Chimeras were mated to C57BL/6J animals to generate fos $\mathrm{B}+/-$ and fos $\mathrm{B}-1-$ mice. These mice were maintained in the animal facility at Bristol-Myers Squibb. Controls for the knock-out mice were heterozygote littermates or wild-type mice of the same genetic background (C57BL/6J)

All experimental group animals received a single intraperitoneal in- 
jection of kainic acid (Sigma, St. Louis, MO) diluted in $0.9 \%$ saline solution $(10 \mathrm{mg} / \mathrm{kg}$ for rats and $18-20 \mathrm{mg} / \mathrm{kg}$ for mice), whereas control animals received a single saline injection. Animals were observed for seizure activity, and only those exhibiting status epilepticus or protracted epileptiform seizures were included in this study. The rodents were killed at various times after the kainate injection by overdoses of Avertin or barbiturates.

Nuclear extract preparation. Nuclear extracts were obtained by a modification of the method of Sonnenberg et al. (1989). Hippocampi were dissected out and immediately homogenized, using a Dounce homogenizer, in 4 volumes (wt/vol) of buffer containing $0.25 \mathrm{M}$ sucrose and (in $\mathrm{mm}$ ): Tris- $\mathrm{HCl} 15, \mathrm{pH} 7.9, \mathrm{KCl} 60, \mathrm{NaCl} 15$, EGTA 1, EDTA 5, spermidine 0.5 , and spermine 0.15 , and the following protease inhibitors: $1 \mathrm{~mm}$ DTT, $0.1 \mathrm{~mm}$ PMSF, $2 \mu \mathrm{g} / \mathrm{ml}$ leupeptin, and $5 \mu \mathrm{g} / \mathrm{ml}$ aprotinin. The homogenate was centrifuged at $2,000 \times g$ for $10 \mathrm{~min}$, and the pellet was resuspended in 4 vol of hypotonic buffer containing $10 \mathrm{~mm} \mathrm{HEPES}, \mathrm{pH}$ 7.9, $1.5 \mathrm{mM} \mathrm{MgCl}_{2}, 10 \mathrm{mM} \mathrm{KCl}$, and the four protease inhibitors. The nuclei were pelleted by centrifugation at $10,000 \times g$ for $20 \mathrm{~min}$ and resuspended in buffer containing 0.5 M HEPES, pH 7.9, 0.75 $\mathrm{mM} \mathrm{MgCl}_{2}$, $0.5 \mathrm{M} \mathrm{KCl}, 12.5 \%$ glycerol, and protease inhibitors. After $60 \mathrm{~min}$ of salt extraction, the nuclei were pelleted by ultracentrifugation at 35,000 $\times g$, and the supernatant was dialyzed overnight against two changes of buffer containing $10 \mathrm{~mm}$ Tris-HCl, pH 7.9, $1 \mathrm{~mm}$ EDTA, $5 \mathrm{mM} \mathrm{MgCl}_{2}, 10 \mathrm{~mm}$ $\mathrm{KCl}, 10 \%$ glycerol, and $1 \mathrm{mM}$ DTT. The entire procedure was performed at $4^{\circ} \mathrm{C}$, and extracts were frozen and stored at $-80^{\circ} \mathrm{C}$.

Gel shift assay. Gel shift assays were performed using a ${ }^{32} \mathrm{P}-$ labeled, $20 \mathrm{bp}$ double-stranded oligonucleotide corresponding to the AP-1 site of the human collagenase gene (5'-AAGCATGAGTCAGACACCTC) (Angel et al., 1987). Binding reactions involved incubating $2 \mu \mathrm{g}$ of nuclear extract with $1 \mu \mathrm{g}$ of poly $(\mathrm{dI}-\mathrm{dC})$ for $10 \mathrm{~min}$ at room temperature. Approximately $10 \mathrm{nM}$ of the radiolabeled oligonucleotide was then added, and the reaction was allowed to incubate for an additional $10 \mathrm{~min}$. The DNA-protein complexes were resolved on a $5 \%$ nondenaturing polyacrylamide gel in high ionic strength buffer containing $25 \mathrm{~mm}$ Tris base and $195 \mathrm{~mm}$ glycine, buffer $\mathrm{pH}$ 8.5. Supershift experiments were conducted by incubating nuclear extracts with $0.5-1 \mu \mathrm{g}$ of affinity-purified polyclonal antibodies specific for the different Fos- and Jun-related proteins (Santa Cruz Biotechnology, Tebu, France) for $60 \mathrm{~min}$ at $4^{\circ} \mathrm{C}$ before the addition of the radiolabeled probe. The gels were vacuum-dried at $80^{\circ} \mathrm{C}$ for $45 \mathrm{~min}$ and exposed to film (Kodak XAR, Rochester, NY).

Western blotting. Hippocampal nuclear extract $(10-20 \mu \mathrm{g})$ was separated on a $3 \%$ stacking $/ 10 \%$ SDS SDS-polyacrylamide gel and electrotransferred at $15 \mathrm{~mA}$ overnight to nitrocellulose. The blots were blocked for $90 \mathrm{~min}$ at room temperature in $4 \%$ nonfat milk (Carnation) in PBS. The blots were then incubated for $90 \mathrm{~min}$ in a $1 \%$ nonfat milk (NFM) blocking buffer containing the primary antibody. The Fra antibody, generated against the M-peptide, recognizes Fos-related antigens and was kindly provided by Dr. M. Iadarola (see Young et al., 1991). FosB proteins were detected with either the Santa Cruz antibody (SC48x) or with an affinity-purified antibody raised against FosB (Kovary and Bravo, 1991). After several washes in PBS, the blots were incubated for $60 \mathrm{~min}$ in a 1:2000 dilution of biotinylated anti-rabbit antibody (Vector Laboratories, Burlingame, CA) in blocking buffer and then for $40 \mathrm{~min}$ in a 1:2500 dilution of streptavidin-HRP conjugate (Amersham, Oakville, Ontario, Canada) in blocking buffer. The blots were washed several times in PBS, developed with the ECL system (Amersham), and exposed to film.

In situ hybridization. At the indicated time points after kainate injection, C57BL/6J mice were anesthetized with $100 \mathrm{mg} / \mathrm{kg}$ sodium pentobarbital and perfused transcardially with a $4 \%$ paraformaldehyde $/ 0.1 \mathrm{M}$ phosphate-buffered solution. The brains were removed, post-fixed for an additional $4 \mathrm{hr}$, and stored at $4^{\circ} \mathrm{C}$ in a $25 \%$ sucrose $/ 0.1 \mathrm{M} \mathrm{NaP}$ solution. Brains were then covered with a thin coating of OCT (Baxter Scientific, Boston, MA) and snap-frozen by immersion in $N$-methylbutane (Aldrich Milwaukee, WI) kept at $-50^{\circ} \mathrm{C}$ with dry ice. Sections $(16-\mu \mathrm{m}$-thick) were cut with a cryostat, and the slides were stored at $-20^{\circ} \mathrm{C}$ until used.

The in situ hybridization was performed as described by Simmons et al. (1989) with minor modifications. After $1 \mathrm{hr}$ of vacuum-drying, the sections were treated with a solution comprising $0.001 \%$ proteinase, 100 $\mathrm{mm}$ Tris, $50 \mathrm{~mm}$ EDTA, pH 8, for $10 \mathrm{~min}$, and then acetylated for another $10 \mathrm{~min}$ with acetic anhydride in $0.1 \mathrm{M}$ triethanolamine, $\mathrm{pH}$. The slides were rinsed in $2 \times \mathrm{SSC}$, dehydrated, and air-dried for $15 \mathrm{~min}$. The sections were hybridized overnight at $55^{\circ} \mathrm{C}$ in buffer $(50 \%$ deionized formamide, $10 \mathrm{~mm}$ Tris, $\mathrm{pH} 7.5,0.6 \mathrm{M} \mathrm{NaCl}, 0.02 \%$ Ficoll, $0.02 \%$ polyvinylpyrrolidone, $0.02 \%$ bovine serum albumin, 1 mM EDTA, $0.1 \%$
SDS, $0.1 \mathrm{mg} / \mathrm{ml}$ salmon sperm DNA, $10 \%$ dextran sulfate, $0.05 \mathrm{mg} / \mathrm{ml}$ total yeast RNA, and $0.05 \mathrm{mg} / \mathrm{ml}$ yeast tRNA) containing 5-10 $\times 10^{5}$ $\mathrm{cpm}$ of ${ }^{33} \mathrm{P}$-labeled riboprobe in a humidified chamber (50\% formamide/4X SSC). The next day, the slides were rinsed for $15 \mathrm{~min}$ in $2 \times$ $\mathrm{SSC}$ and incubated for $30 \mathrm{~min}$ at $37^{\circ} \mathrm{C}$ in an RNase A solution (10 mM Tris, pH 7.5, $0.5 \mathrm{~m} \mathrm{NaCl}, 1 \mathrm{~mm}$ EDTA, and $100 \mu \mathrm{g} / \mathrm{ml}$ RNase A). The slides were rinsed in the same buffer, minus the enzyme, for $30 \mathrm{~min}$ at $50^{\circ} \mathrm{C}$ and washed in $2 \times \mathrm{SSC}$ and $0.2 \times \mathrm{SSC}$ for 1 and $2 \mathrm{hr}$, respectively, at $60^{\circ} \mathrm{C}$. After dehydration and drying, the sections were exposed overnight to Hyperfilm b-max (Amersham) at room temperature. Emulsion autoradiography was performed by coating the slides with NTB-2 emulsion (Kodak) and exposed for 5-7 d. After development, the sections were counterstained with a $0.01 \%$ toluidine blue solution.

The probes used in these experiments consisted of sense and antisense sequences corresponding to either a 500 bp fragment of the mouse fos $\mathrm{B}$ gene (bases 1209-1708) or a PCR-amplified fragment spanning the 140 bp splice site absent from $\Delta$-fos B mRNA. Thus, the latter probe only detects the full-length fos $\mathrm{B}$ transcript, whereas the former cannot discriminate between the two mRNA species. Note that the specific activity of the two probes was not equivalent or corrected for size differences; therefore, direct comparison of signal intensity is not possible.

Immunohistochemistry. Sections through the hippocampal region of fos $\mathrm{B}-/-$ mice and heterozygote littermates were stored at $4^{\circ} \mathrm{C}$ until ready for use. Sections were washed in PBS for $30 \mathrm{~min}$ and then incubated for $60 \mathrm{~min}$ at room temperature in a $4 \%$ nonfat milk blocking buffer supplemented with $5 \%$ normal goat serum (Vector Labs), $0.5 \%$ Triton X-100. After removal of the blocking buffer, either a 1:5,000 dilution of the SC 48x FosB antibody or a 1:10,000 dilution of our own purified FosB antibody in a $1 \%$ NFM $/ 1 \%$ normal goat serum $/ 0.1 \%$ Triton X-100 blocking buffer was added for $24-48 \mathrm{hr}$ at $4^{\circ} \mathrm{C}$. The sections were washed several times with PBS and incubated with a 1:200 dilution of biotinylated anti-rabbit IgG (Vector Labs) in 1\% blocking buffer for 60 min at room temperature. After immersion in avidin-biotin complex for $60 \mathrm{~min}$ and three washes with PBS, immunoreactivity was visualized by color development using diaminobenzidine as described in the manufacturer's instructions (Vectastain ABC kit, Vector).

\section{RESULTS}

Recent studies demonstrated the protracted expression of AP-1like DNA-binding activity in the rat brain after chronic cocaine administration, electroconvulsive shock, and drug-induced seizure activity (Hope et al., 1992, 1994a,b; Kaminska et al., 1994; Pennypacker et al., 1994; Kasof et al., 1995). Figure 1A shows that this phenomenon also occurs in the mouse. Under control conditions, AP-1-like DNA-binding activity was low in both rat and mouse hippocampus, but levels increased dramatically within $2 \mathrm{hr}$ of treatment with kainic acid. Although AP-1-like binding subsequently declined, it remained above basal levels for at least $10 \mathrm{~d}$ in both species (Fig. $1 A$; data not shown). The AP-1 shifts were composed predominantly of two bands (Fig. 1 $A$ ). During the acute phase of treatment, both bands of AP-1 activity were increased in intensity, whereas at longer times, only the more rapidly migrating band was elevated (Figs. $1 A, 2,3$ ).

Several studies have reported that the persistently elevated AP-like DNA-binding activity seen in the rat brain is constituted by complexes that contain FosB-like molecules (Hope et al., 1994; Kaminska et al., 1994; Chen et al., 1995). As shown in Figure 1B, the chronic AP-1 shift that was induced in the rat and two strains of mice by kainic acid treatment was completely supershifted by an antiserum specific for FosB. Thus, as in rat, in mice the protracted increase in AP-1-like DNA-binding activity was attributable to FosB-like molecules.

Because the molecular characterization of the AP-1 shifts relied on immunological criteria, the experiment was repeated on fos B-null mice. Although fosB-null mice show an age-dependent predisposition to seizures (Gruda et al., 1996), there were no qualitative differences in the time of onset, duration, or apparent intensity of the seizures induced by kainic acid in young fos $\mathrm{B}-/-$ 
A

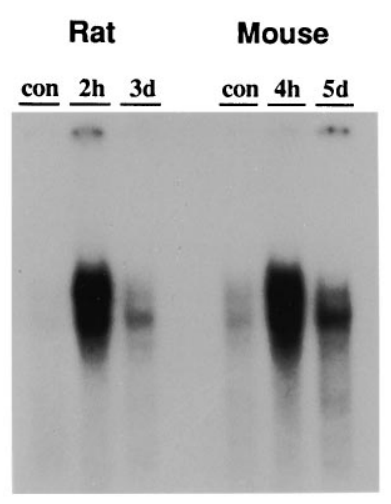

B

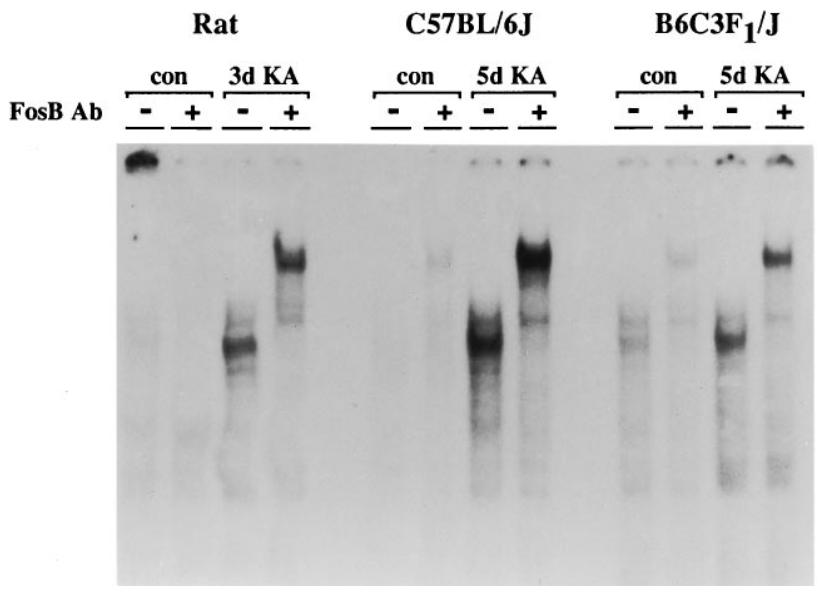

Figure 1. Protracted increase in AP-1-like DNA-binding activity in the rat and mouse hippocampus after kainate treatment. $A$, Representative autoradiogram of a gel mobility shift assay showing basal and stimulated AP-1-like DNA binding in rat and mouse hippocampal nuclear extracts after a single kainate injection. The autoradiogram is overexposed to facilitate visualization of basal AP-1 complexes. $B$, Autoradiogram of a supershift experiment performed on rat and mouse hippocampal nuclear extracts $3 \mathrm{~d}$ after saline (con) or kainic acid $(K A)$ treatment. The extracts were preincubated with $1 \mu \mathrm{g}$ of a FosB antibody (+) or nonimmune serum $(-)$ for $1 \mathrm{hr}$ at $4^{\circ} \mathrm{C}$ before the addition of the radiolabeled AP-1 oligonucleotide.

mice compared with wild-type mice of the same age and genetic background.

Nuclear extracts from fos $\mathrm{B}+/+$ and $-/-$ mice had low basal levels of AP-1-like DNA-binding activity that increased at $4 \mathrm{hr}$ after kainic acid treatment (Fig. 2). During the acute phase, the lower AP-1 band was much less evident in fos $\mathrm{B}-1-$ mice (Fig. 2, arrows). At $5 \mathrm{~d}$ after treatment, the fos $\mathrm{B}+/+$ mice showed the typical chronic expression of the lower band of AP-1 binding that was supershifted by the FosB antiserum (Fig. 2). However, there was no evidence of any increased AP-1-like DNA-binding activity in fos $\mathrm{B}-/-$ mice (Fig. 2). Thus, a functional fos $\mathrm{B}$ allele is essential for the formation of the chronic AP-1 shift observed after kainic acid treatment.

To obtain additional information on the composition of the chronic AP-1 shift and to determine whether the absence of FosB results in compensatory changes in other components of AP-1 complexes, a supershift analysis was performed (Fig. 3). Extracts from control fos $\mathrm{B}+/+$ mice exhibited three bands of AP-1-like

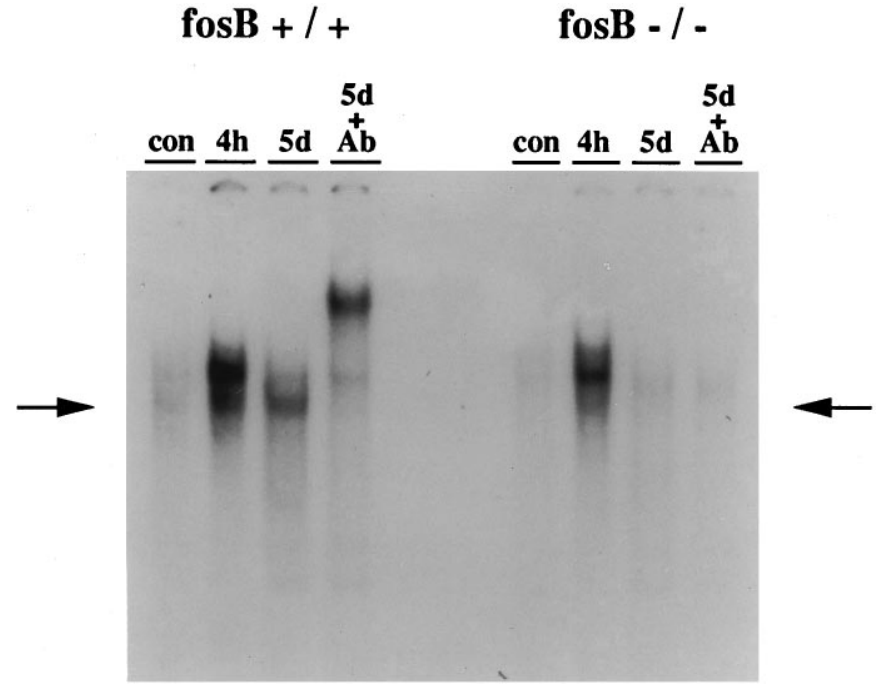

Figure 2. AP-1-like DNA-binding activity in wild-type and fosB-/mouse hippocampus after kainic acid treatment. Autoradiogram of a gel mobility shift assay showing AP-1-like DNA-binding activity in hippocampal nuclear extracts under control (con) conditions, and $4 \mathrm{hr}$ and $5 \mathrm{~d}$ after a single kainate injection. Lane 4 represents a supershift of the $5 \mathrm{~d}$ sample using a FosB-selective antiserum. The arrows indicate the position of the lowest AP-1 band that is selectively shifted by the FosB antiserum and that is absent in $f o s \mathrm{~B}-/-$ mice.

DNA-binding activity. The weak upper band was shifted by the Fra2 antiserum, whereas the lowest and strongest band was completely supershifted by the FosB antiserum. The Fos and Fra1 antibodies had no effect. JunD and JunB antibodies supershifted all three bands, whereas Jun antibodies did not produce any shift. These results indicated that FosB and Fra2 contributed to distinct AP-1 bands, whereas JunB and JunD participated in all complexes. In addition, FosB was the major contributor to basal AP-1 binding. Basal AP-1-like DNA-binding activity in fos $\mathrm{B}-/-$ mice lacked the lowermost band. Consistent with this, the FosB antiserum did not produce any supershift in basal extracts from fos $\mathrm{B}-1-$ mice. The Fra2 antibody again supershifted the uppermost AP-1 band, whereas the JunB and JunD antibodies influenced the migration of both bands. The Fra2 antiserum appeared to give consistently higher shifts in fos $\mathrm{B}-/-$ mice, whereas Fos and Jun supershifts were only seen on longer exposures.

Three hours after kainic acid treatment, there was a marked elevation in AP- 1 binding in fos $\mathrm{B}+/-$ mice. This was attributable to increases in the intermediate band, which became the predominant shift and the lowermost band of AP-1 binding. The intermediate band was supershifted by the Fos and JunB antibodies, with minor contributions from Jun and JunD, indicating that these were Fos-JunB complexes. The lower AP-1 band was supershifted and/or depleted by the FosB, Fos, and JunB antisera, whereas antisera to Jun and JunD had small effects. From these data, it is concluded that the lowermost inducible AP-1 shift is predominantly composed of Fos-JunD, FosB-JunB, and FosBJunD heterodimers. The weak upper band that was composed of Fra2-like material in control extracts was obscured by the intense signal from the middle band. However, the presence of this upper band could be inferred by the weak supershift produced with the Fra2 antiserum (Fig. 3). Unlike Fos and FosB, the level of Fra2-like material did not increase after seizure. Extracts from fos $\mathrm{B}-1-$ mice also showed markedly increased AP-1 binding $3 \mathrm{hr}$ after administration of kainic acid (Fig. 3). The compositions of 


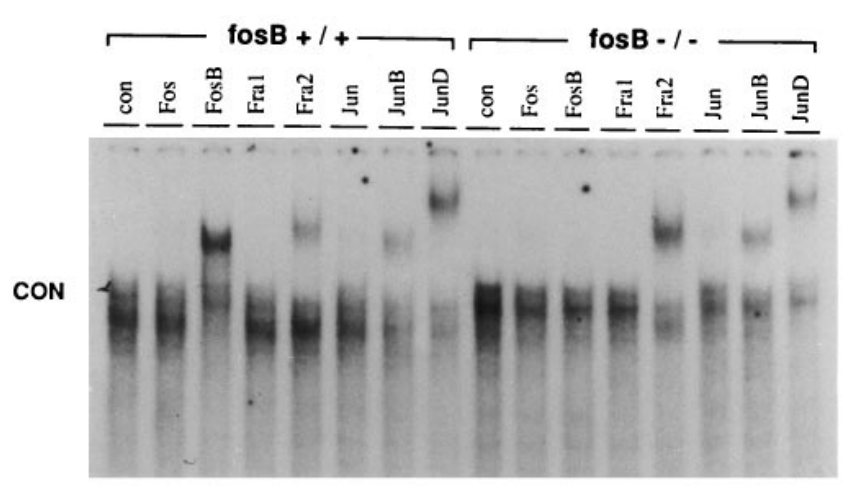

3 h KA

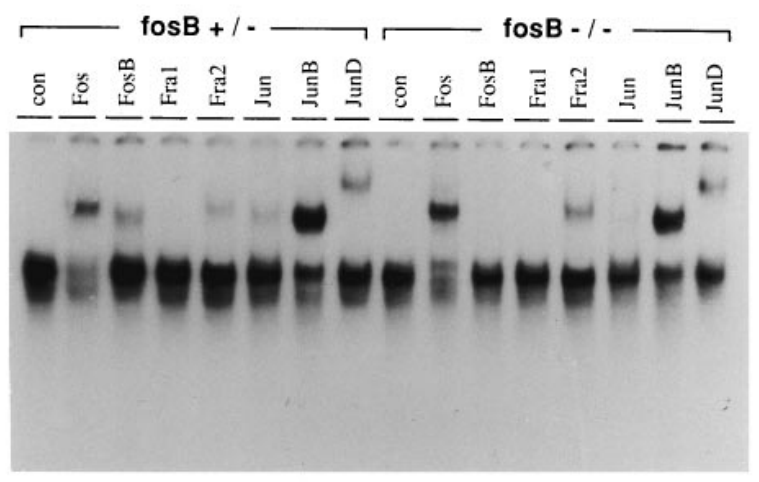

4 d KA

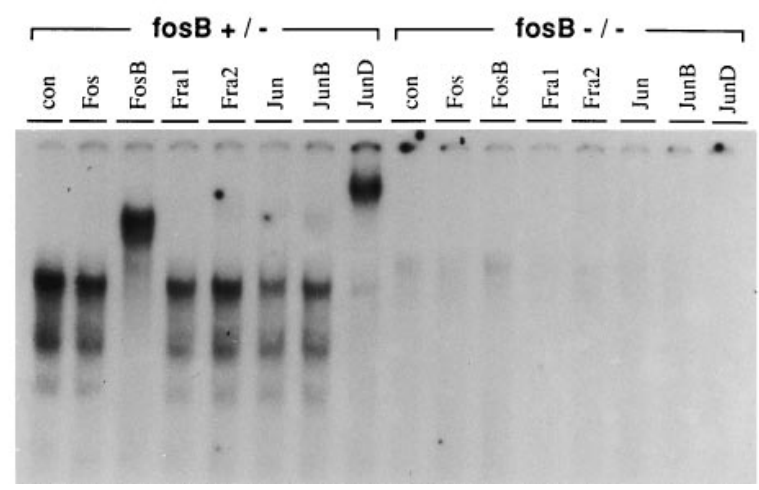

Figure 3. The protracted AP-1-DNA-binding complex is composed predominantly of FosB-JunD heterodimers. Autoradiograms showing antibody supershift analyses of hippocampal nuclear extracts from wild-type (fos $\mathrm{B}+/+$ and $+/-$; lanes 1-8) and fos $\mathrm{B}-/-$ (lanes 9-16) mice after kainate treatment. The extracts were preincubated with $1 \mu \mathrm{g}$ of the indicated antibodies for $1 \mathrm{hr}$ at $4^{\circ} \mathrm{C}$ before addition of the radiolabeled oligonucleotide. The chronic AP- 1 shift is absent in $f o s \mathrm{~B}-/-$ mice but is observed in $f o s \mathrm{~B}+/-$ animals. The chronic AP- 1 band is supershifted by FosB and JunD antisera. Note additional, apparently smaller AP-1 complexes that are supershifted by the same antisera and that are also absent in $f o s \mathrm{~B}-/-$ mice.

the bands was essentially the same as that determined for wildtype and fos $\mathrm{B}+/-$ mice except that the FosB antiserum produced no supershift. Other than the absence of FosB-like material, there were no consistent qualitative or quantitative differences in the AP-1 shifts from fos $\mathrm{B}+/-$ or fos $\mathrm{B}-/-$ mice with the exception of possibly higher levels of Fra2 in the latter.
Four days after kainate treatment, the lowermost band of AP-1 binding was still elevated in $f o s \mathrm{~B}+/-$ mice, whereas the intermediate and upper bands had returned to basal values (Fig. 3). A number of apparently lower molecular weight complexes were also evident in fos $\mathrm{B}+/-$ mice at 4 (Fig. 3) and 5 (Fig. 1) days after treatment. All of these AP-1 bands were supershifted by the FosB and JunD antisera. In some experiments, the intermediate AP-1 band was evident (Figs. 1, 2), but this was not supershifted by the FosB antisera (Figs. 1, 2). In fos B-null mice, there was only marginal AP-1 binding at the position of the intermediate band and no evidence of any chronic shift. Moreover, there was no supershift with the FosB antiserum. Therefore, it is concluded that the chronic AP-1 shift is attributable to heterodimers containing JunD- and FosB-like proteins.

The finding of multiple chronic AP-1 shifts that cross-reacted with the FosB antiserum suggested that more than one protein derived from the fos $\mathrm{B}$ allele may be persistently elevated. Therefore, to confirm and extend the gel shift analysis, nuclear extracts from $f o s \mathrm{~B}+/-$ and $f o s \mathrm{~B}-/-$ mice were analyzed by immunoblotting. Figure $4 A$ shows the results using an antibody raised against c-Fos that cross-reacts with all Fos-related proteins. Under basal conditions, two Fos-like immunoreactive bands in the 40-45 kDa range were observed in $f o s \mathrm{~B}+/-$ but not in $f o s \mathrm{~B}-/-$ mice. Four hours after kainate treatment, there was a marked increase in Fos-related proteins in both heterozygote and fosB-null mice. A doublet at $\sim 55-60 \mathrm{kDa}$ is most likely authentic c-Fos and was present in mice of both genotypes. Another doublet at $\sim 45 \mathrm{kDa}$ and additional bands in the range of $25-40 \mathrm{kDa}$ were also induced in $f o s \mathrm{~B}+/-$ mice but were absent in $f o s \mathrm{~B}-/-$ animals. At $4 \mathrm{~d}$ after treatment, a broad, intense $35-37 \mathrm{kDa}$ band of Fos-like immunoreactivity was observed in $f o s \mathrm{~B}+/-$ but not in $f o s \mathrm{~B}-/-$ mice. Two additional weak bands of Fos-like immunoreactivity at $37-42 \mathrm{kDa}$ were evident in both treated and untreated fos $\mathrm{B}+/-$ and $f o s \mathrm{~B}-/-$ mice. Because these bands were not detected with an FosB specific antiserum (Fig. 4B), they must be the product of another gene that is not induced in this paradigm, such as fra2. In addition to these species, lower molecular weight bands were present in the heterozygous fos $\mathrm{B}$ mice that were absent in the fos B-null mice. Similar results were obtained using pooled extracts from 5 fos $\mathrm{B}+/-$ and $f o s \mathrm{~B}-/-$ mice $4 \mathrm{~d}$ after kainate treatment. These data imply that multiple FosB-related proteins are induced by kainic acid and that some of these are chronically expressed. To confirm this, the same blot was stripped and reprobed with the FosB-specific antibody used in the supershift experiments.

The FosB-specific antiserum detected a $45 \mathrm{kDa}$ doublet in fos $\mathrm{B}+/-$ mice that was induced at $4 \mathrm{hr}$ but returned to baseline by $4 \mathrm{~d}$ after treatment. This doublet was absent in fosB-null mice. The size of these proteins is consistent with them being fulllength FosB. Because most members of the Fos and Jun families are phosphoproteins, it is possible that the doublet is attributable to different degrees of phosphorylation. Two additional proteins at $\sim 35 \mathrm{kDa}$ were also induced in fos $\mathrm{B}+/-$ but not fos $\mathrm{B}$-null mice. The sizes of these proteins are in the range of $\Delta$-FosB. Thus, they may be differentially phosphorylated products of the $\Delta-$ fos B splice variant. Beside these prominent bands, a minor cross-reactive protein was observed in the range of $28 \mathrm{kDa}$ in $f o s \mathrm{~B}+/-$ but not fos $\mathrm{B}-/-$ mice. At the $4 \mathrm{~d}$ time point, two bands of FBLI were evident at $\sim 28$ and $37 \mathrm{kDa}$. The major band $(37 \mathrm{kDa})$ migrated slightly slower than the proteins in this range at the $4 \mathrm{hr}$ time point. Because this protein was only observed in fos $\mathrm{B}+/-$ mice, it is possible that it is derived by post-translational modification of 


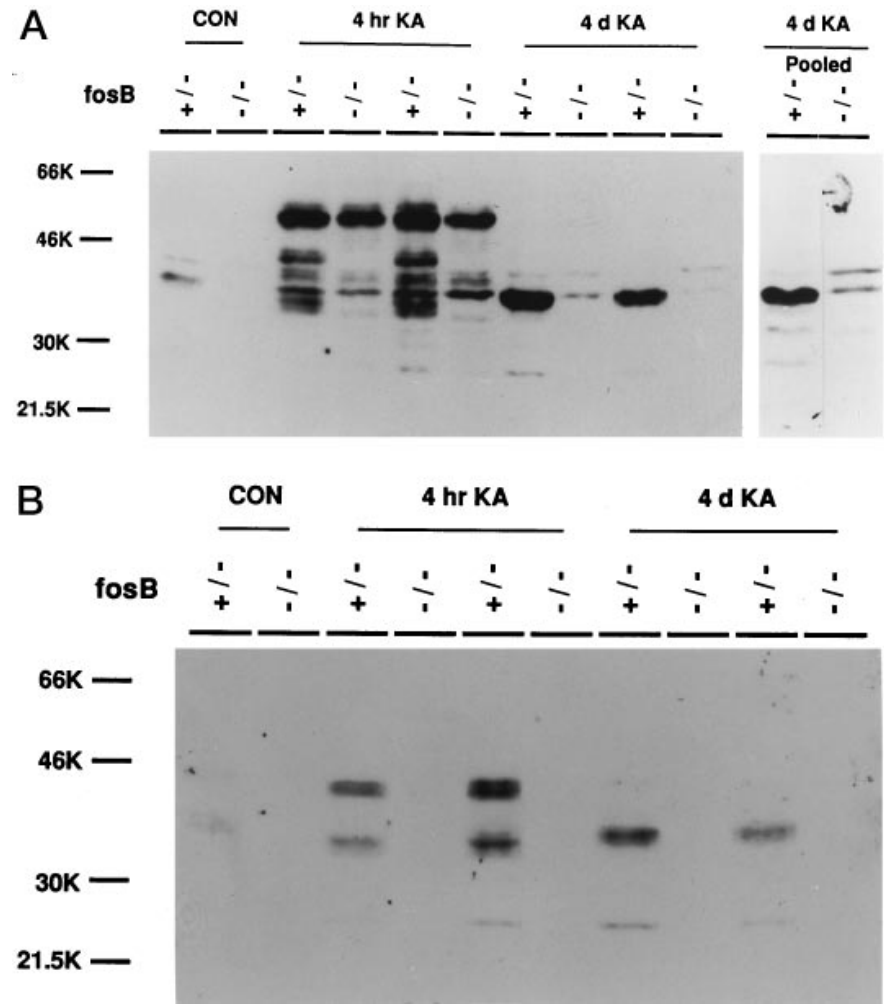

Figure 4. Persistent expression of a truncated FosB-like protein after a single kainate treatment. $A$, Immunoblot using a pan-Fos family antiserum on nuclear extracts from fos $\mathrm{B}+/-$ and fos $\mathrm{B}-/-$ mouse hippocampi after kainic acid treatment. During the acute phase ( $4 h r K A)$, approximately equivalent levels of Fos $(\sim 58 \mathrm{kDa}$ Fra $)$ were induced in both genotypes. However, a number of lower molecular weight inducible Fras were absent in the fos $\mathrm{B}-/-$ extracts. The doublet at $\sim 45 \mathrm{kDa}$ is likely to be FosB, whereas the series of bands in the range of $35-37 \mathrm{kDa}$ are consistent with $\Delta$-FosB. In chronically treated mice ( $4 d K A$ ), one dominant Fra is apparent at $37 \mathrm{kDa}$ in $f o s \mathrm{~B}+/-$ but not $f o s \mathrm{~B}-/-$ mice. An additional, weaker band at $\sim 28 \mathrm{kDa}$ has the same properties. Two independent mice were used for each time point. The $4 \mathrm{~d}$ result was confirmed using pooled extracts from an additional five mice of each genotype and is shown in the right panel. $B$, Immunoblotting of nuclear extracts from $f o s \mathrm{~B}+/-$ and $f o s \mathrm{~B}-/-$ mice using a FosB-specific antiserum. The pan-Fos immunoblot used in $A$ was stripped of bound antibody and reprobed with a FosB-specific antiserum. The FosB antiserum detects the $46 \mathrm{kDa}$ doublet (FosB) and bands in the $35-37 \mathrm{kDa}$ range $(D-F o s B)$ in extracts from fos $\mathrm{B}+/-$ but not fos $\mathrm{B}-/-$ mice. The $\sim 28 \mathrm{kDa}$ band was also selectively detected in fos $\mathrm{B}+/-$ mice. The $45 \mathrm{kDa}$ bands are absent in the $4 \mathrm{~d}$ post-treatment extracts, which contain the 28 and $37 \mathrm{kDa}$ bands. Note that the $37 \mathrm{kDa}$ band seen in the $4 \mathrm{~d}$ extract migrates slightly slower than the predominant $\Delta$-FosB band observed in the $4 \mathrm{hr}$ extract.

the $\Delta$-FosB-like proteins seen at $4 \mathrm{hr}$. Alternatively, it may represent the product of a new splice variant of fos $\mathrm{B}$. The $\sim 28 \mathrm{kDa}$ protein was also only present in $f o s \mathrm{~B}+/-$ mice. Its identity is unknown, although it could be a proteolytic fragment of FosB or $\Delta$-FosB, or a novel splice variant. Together, these data demonstrate that a $37 \mathrm{kDa} \Delta$-FosB-like protein accounts for the majority of the chronically elevated AP-1 DNA-binding activity seen after kainic acid treatment. In addition, a smaller protein that crossreacts with two FosB antisera and that is absent in fos B-null mice may contribute to the rapidly migrating chronic AP- 1 complexes.

The above experiments demonstrated that kainate-induced seizure activity resulted in the long-term expression of one or more truncated FosB proteins. To investigate whether this protracted induction resulted from transcriptional processes, we ex-

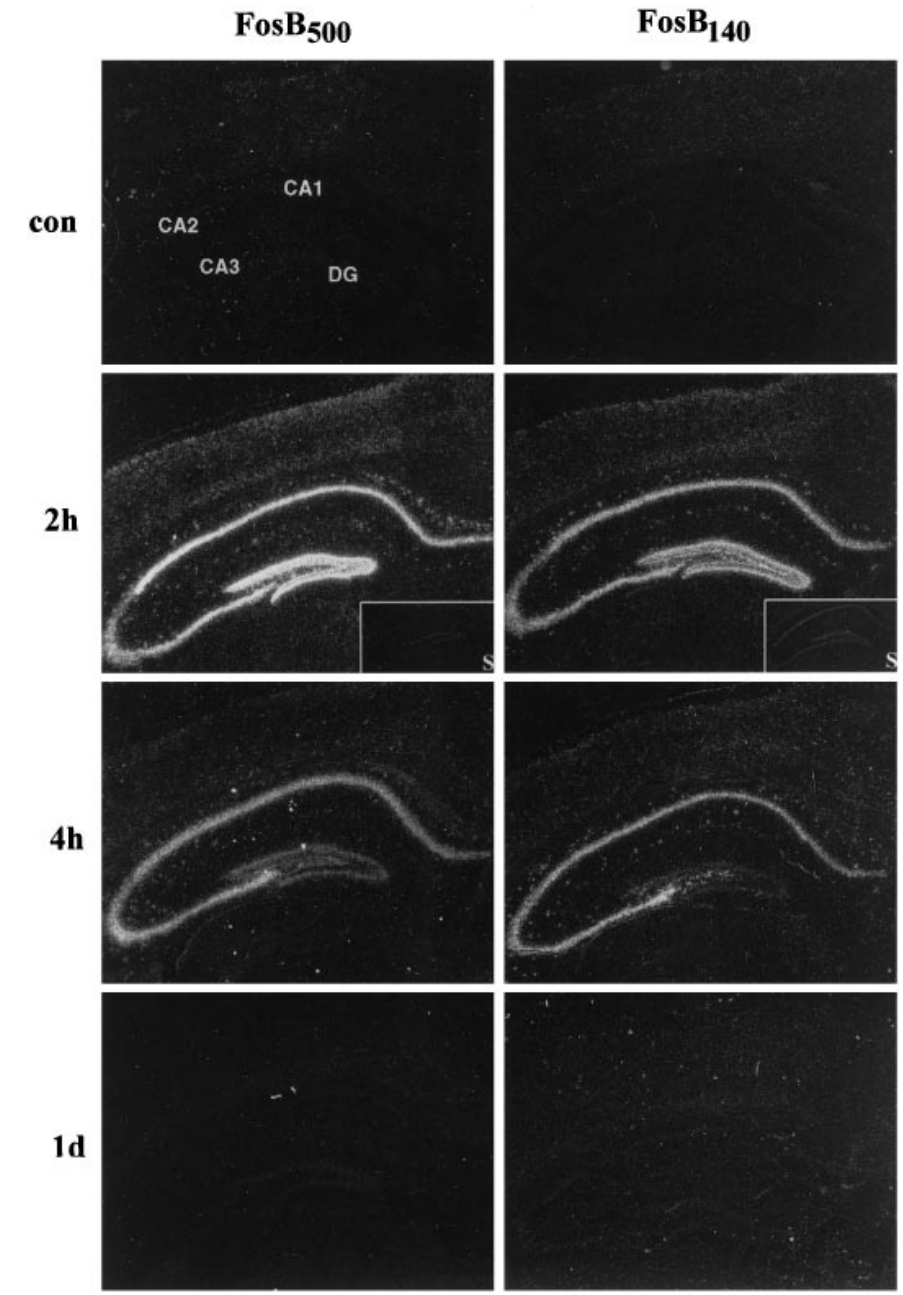

Figure 5. fos B mRNA is expressed transiently in the hippocampus after kainate treatment. In situ hybridization of hippocampal sections from wild-type mice after kainate treatment. Each section was hybridized overnight with either a 500 base $\left(F o s B_{500}\right)$ or a 140 base $\left(F o s B_{140}\right)$ radiolabeled antisense probe specific for both fos $\mathrm{B}$ and $\Delta-f o s \mathrm{~B}$, or fos $\mathrm{B}$, respectively. Neither probe detects fos $\mathrm{B}$ transcripts in control (con) mice. At $2 \mathrm{hr}$ after treatment, strong signals from both antisense probes are observable over the neuronal components of the dentate gyrus and layers CA1 and CA3. Hybridization is also evident in layers $2 / 3$ and $5 / 6$ of the cerebral cortex. No signal is observed when the probes are applied in their sense orientation (inset $S$ ), further indicating specificity. Hybridization signals begin to decline by $4 \mathrm{hr}$ after treatment and are indistinguishable from background at $1 \mathrm{~d}$.

amined the expression of fos $\mathrm{B}$ mRNA in wild-type mice using in situ hybridization. fos $\mathrm{B}$ and $\Delta$-fos $\mathrm{B}$ transcripts differ only by the deletion of an internal 140 base segment (exon 4) in the latter (Dobrzanski et al., 1991; Mumberg et al., 1991; Nakabeppu and Nathans, 1991; Yen et al., 1991). Therefore, we implemented an in situ paradigm that could differentiate the expression of fos $\mathrm{B}$ from $\Delta$-fos B. A 140 base probe was complementary to the deleted sequence in $\Delta$-fos $\mathrm{B}$ and only hybridized with the full-length fos $\mathrm{B}$ transcript. In contrast, a 500 base probe hybridized to a common sequence $5^{\prime}$ of the splice site and detected both mRNAs. Thus, if $\Delta$-fos B were the sole, or predominant, transcript, hybridization signal would be seen with the FosB-500 probe but not with the FosB-140 probe.

There was minimal hybridization of either probe to hippocampal sections from untreated mice (Fig. 5). However, at $2 \mathrm{hr}$ after 


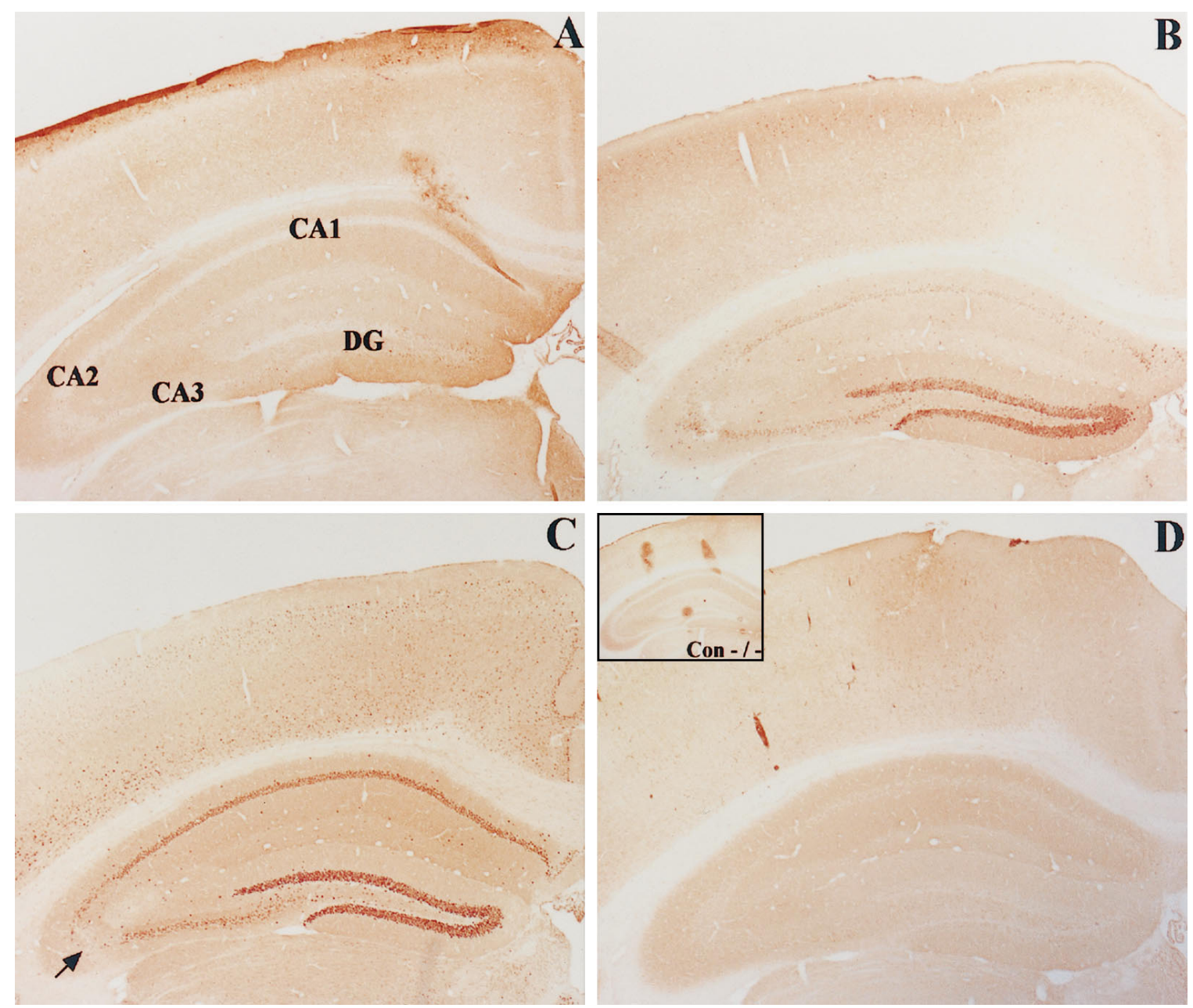

Figure 6. FBLI is chronically expressed in all regions of the hippocampus in $f o s \mathrm{~B}+/-$ but not not fos $\mathrm{B}-/-$ mice. FosB immunostaining of coronal sections through the hippocampal region of $f o s \mathrm{~B}+/-(A-C)$ and fos $\mathrm{B}-/-$ mice $(D)$. All sections were incubated for $24-48 \mathrm{hr}$ at $4{ }^{\circ} \mathrm{C}$ with a $1: 2500$ dilution of a FosB-specific antibody. Control mice $(A)$ have no FosB staining in the hippocampus, except for a few positively stained nuclei in the dentate gyrus. $B$ and $C$ show FosB-positive neurons throughout the hippocampus $4 \mathrm{hr}$ and $4 \mathrm{~d}$ after kainic acid treatment, respectively. There is also significant FosB staining in several layers of the cortex at $4 \mathrm{~d}$ after treatment. At $4 \mathrm{~d}$ after administration of kainic acid, signs of neuronal degeneration become apparent in the CA3 area $(C$, arrow). $D$ shows a complete absence of positively stained cells in the hippocampus of fos $\mathrm{B}-/-$ mice, both under basal conditions (inset) and $4 \mathrm{~d}$ after kainic acid treatment. Magnification, $25 \times$.

kainic acid treatment, strong signals were observed with both probes throughout the hippocampus as well as in the cerebral cortex. The strongest expression occurred in the dentate gyrus, CA1, and proximal CA3 regions. Little or no hybridization was seen with the sense orientation of the two probes (Fig. 5, inset), indicating specificity of the hybridization signal. Increased hybridization to both probes was still evident at $4 \mathrm{hr}$ after treatment, although intensity was already declining and by $1 \mathrm{~d}$, the signal was back at background levels. From these results, it can be inferred that full-length (i.e., unspliced) fos B was expressed transiently in various neuronal populations after kainic acid treatment. Although hybridization of the FosB500 probe suggested a proportionately higher contribution of $\Delta-f o s \mathrm{~B}$ transcripts at $2 \mathrm{hr}$, it was not possible to establish unambiguously what contribution $\Delta-f o s \mathrm{~B}$ transcripts represented. In RT-PCR experiments performed on RNA isolated from kainate-stimulated rat hippocampus, both fos $\mathrm{B}$ and $\Delta$-fos $\mathrm{B}$ transcripts were detected at early times after treatment in approximately equal abundance (data not shown). However, the issue is somewhat moot, because by $1 \mathrm{~d}$ after treatment, there was no evidence for elevated levels of either fos $\mathrm{B}$ or $\Delta$-fos $\mathrm{B}$ transcripts. This again raised the paradox of persistently elevated $\Delta$-FosB in the absence of increased $\Delta$-fosB mRNA.

In light of the discordance between mRNA and protein measurements, we examined the expression of FBLI by immunohistochemistry in the brains of wild-type and fos $\mathrm{B}-/-$ mice after kainic acid treatment. Figure $6 A$ shows that under basal conditions, only sporadic neurons in the dentate gyrus exhibited any FBLI in fos $\mathrm{B}+/-$ mice. By $4 \mathrm{hr}$ after treatment, FBLI was expressed throughout the hippocampal formation, as well as in some cells in the upper layers of the cortex (Fig. 6B). The strongest induction occurred in the dentate gyrus, followed by CA1 and CA3. Very few nuclei were stained in the CA2 region. The results in control and acutely treated mice were consistent with the in situ hybridization data. However, FBLI continued to increase through day 4 after treatment, and regional differences in expression started to emerge (Fig. 6C). For example, neurons in the dentate gyrus and CA1 became intensely immunopositive, whereas CA3 neurons were stained to approximately the same extent as they were at $4 \mathrm{hr}$. In addition, cells in CA2 began to 
express FBLI, as did many neurons in layers $2 / 3$ and $5 / 6$ of the cerebral cortex. The less robust staining of CA3 neurons was consistent with the in situ hybridization data in that the infrapyramidal region of CA3 showed less hybridization (Fig. 5). However, because neuronal degeneration is already evident in this area (Fig. 6C, arrow), the effect may be attributable to cell loss. Nevertheless, two independent antisera to FosB (Fig. 6; data not shown) show that there was a persistent accumulation of FBLI in neuronal populations that were widely dispersed in the brain. One possible explanation of the discrepancy between in situ hybridization and immunohistochemical detection of FBLI is that the antisera cross-react with another protein. Therefore, to exclude this possibility, the experiment was repeated on fos B-null mice. In control and kainic acid-treated fos $\mathrm{B}-/-$ mice, there was no immunostaining for FBLI at any time examined (Fig. 6D). However, these mice do show the acute induction of Fos-like immunoreactivity after treatment with kainic acid (data not shown). These data indicate that the FBLI is derived from, or dependent on, the fos $\mathrm{B}$ allele.

\section{DISCUSSION}

Immunological and biochemical analyses in wild-type and fos $\mathrm{B}-1-$ mice establish that the persistently elevated AP-1-like DNA-binding activity seen after administration of kainic acid is attributable to a truncated form of FosB in complex with JunD. The predominant fos B-derived protein in these AP-1 complexes is an $\sim 37 \mathrm{kDa}$ species, that is, probably a post-translationally modified form of $\Delta$-FosB. A less abundant, lower molecular weight fos B-derived protein was also identified that may contribute to additional, persistent AP-1 complexes that migrate quicker than $\Delta$-FosB-JunD and FosB-JunD heterodimers in gel retardation assays. The identity of this protein is uncertain, although it may be a proteolytic cleavage product of FosB or $\Delta$-FosB.

In both rat and mouse, there is a discordance between the level of $\Delta$-FosB and its mRNA. A number of potential explanations could account for this discrepancy. The first is that the protein is the product of another gene. However, the present data establish that the FBLI is derived from, or dependent on, the fos $\mathrm{B}$ allele. The second possibility is that the protein is translated from a novel splice variant of fos $\mathrm{B}$ that does not hybridize (well) to the various fos $\mathrm{B}$ probes. Although this is theoretically possible, multiple probes from different regions of the fos $\mathrm{B}$ mRNA fail to detect additional transcripts by in situ hybridization and Northern blotting (Fig. 5) (Zerial et al., 1989; Nakabeppu and Nathans, 1991; Kaminska et al., 1994; Chen et al., 1995; Kasof et al., 1995). Therefore, the most likely explanation is that the $37 \mathrm{kDa} \Delta$-FosBlike protein has a very long half-life.

Several scenarios involving protein half-life can be envisioned that account for the persistence of the $37 \mathrm{kDa}$ FosB. However, a prerequisite of these explanations is that they accommodate the fact that fos $\mathrm{B}$ is induced transiently in many situations without the persistent expression of FBLI. The most plausible mechanism would be to suppose that the long half-life of the $37 \mathrm{kDa}$ protein is conferred by a stimulus-dependent post-translational modification. For example, FosB could undergo stimulus-specific proteolytic processing to yield a very stable fragment. Alternatively, the $37 \mathrm{kDa} \Delta$-FosB-like protein could be translated from the $\Delta$-fosB mRNA generated in the acute phase of the response but undergo stimulus-dependent post-translational modification, such as phosphorylation. There is some evidence for the latter scenario in the immunoblots of kainic acid-treated mouse hippocampal extracts.
A cluster of three $\Delta$-FosB-like bands in the range of $35-37 \mathrm{kDa}$ is seen in $f o s \mathrm{~B}+/-$ but not fos $\mathrm{B}-/-$ mice. The lower two bands of FBLI were most prominent at $4 \mathrm{hr}$ but were absent at $4 \mathrm{~d}$ after treatment. The upper, $37 \mathrm{kDa}$ band was relatively low at $4 \mathrm{hr}$ but increased thereafter to constitute the chronic FBLI band. Therefore, it is possible that these three bands represent sequentially modified forms of $\Delta$-FosB. The two smaller species seem to have relatively short half-lives and be the forms of $\Delta$-Fos present in the conventional acute cIEG responses. The $37 \mathrm{kDa}$ FBLI band seems to have a long half-life. Because the $37 \mathrm{kDa}$ band accumulates during the time that fos $\mathrm{B}$ mRNA and the lower bands of FBLI disappear, it may be derived from the latter, possibly through a stimulus-dependent modification. There is precedent for differential phosphorylation of Fos. Both NGF and depolarization trigger phosphorylation of Fos, but the phosphoprotein migrates at an apparently higher molecular weight in NGFtreated cells (Morgan and Curran, 1986). Whether neurotrophins are the agents that specifically promote the formation of the 37 $\mathrm{kDa}$ FBLI band is unknown, although they are known to be induced by kainic acid treatment (Zafra et al., 1990; Gall et al., 1991; Rudge et al., 1995).

The principal issue that remains is the functional significance of the $37 \mathrm{kDa} \Delta$-FosB. Seizures are well known to elicit an immediate-early gene response in many neuronal populations in the brain (Morgan and Curran, 1991b). Because this response is typically transient, the cIEGs are thought to exert their effect by providing a link between brief periods of neuronal activation and adaptive/plasticity responses in the brain by altering the expression of other genes. For example, the transcription of genes encoding enzymes that modify the extracellular matrix, such as collagenase and stromelysin, are regulated by AP-1 complexes (Angel et al., 1987; Kerr et al., 1988; Schonthal et al., 1988). Similarly, the expression of proteins believed to be involved in neuronal structure and plasticity, such as GAP43, is induced by seizures (Nedivi et al., 1992; Bendotti et al., 1993; Meberg et al., 1993). In addition, a number of neurotrophins and their receptors are induced by seizures and may be subject to AP-1-mediated regulation (Gall and Isackson, 1989; Zafra et al., 1990; Ernfors et al., 1991; Isackson et al., 1991; Bengzon et al., 1993). Thus, many of the molecules, the expression of which may be influenced by AP-1 transcription factor complexes, can potentially contribute to the physical growth of neurons. For example, metalloproteinases could sculpt the extracellular matrix to permit sprouting, GAP43 might promote growth cone extension, and neurotrophins may activate signal transduction pathways that recruit additional growth and transcriptional responses. However, this scenario is based on associational studies, and there is little direct evidence linking any particular cIEG to a neuronal growth response in vivo. Recently, this situation changed with the demonstration that the absence of a functional c-fos allele resulted in a reduction in mossy fiber sprouting and attenuated kindling (Watanabe et al., 1996). This implies that Fos contributes positively to epileptogenesis, perhaps by facilitating sprouting.

The present data add an additional dimension to the involvement of cIEGs in neuronal plasticity and adaptation. In the original formulation of the cIEG response was the notion that it should be subject to negative feedback regulation. Indeed, the cIEG response exhibits refractory properties, although the molecular basis of this is unclear (Morgan et al., 1987; Winston et al., 1990; Hope et al., 1992). The present data establish that the same stimulus that triggers the transient expression of many cIEGs in the brain elicits the chronic expression of $37 \mathrm{kDa} \Delta$-FosB-JunD 
complexes in neurons. However, the absence of a functional fos $\mathrm{B}$ allele, rather than reducing the predisposition to seizures, actually increases it (Gruda et al., 1996) (M. Gruda, unpublished observations). This suggests that $\Delta$-FosB and perhaps other proteins derived from the fos $\mathrm{B}$ allele function to oppose some of the processes set in train by the cIEG response.

$\Delta$-FosB lacks a domain that is involved in conferring transactivational potential on FosB. For example, Fos and FosB can both transform cells, whereas $\Delta$-FosB either has weak activity (Kovary et al., 1991) or does not transform at all (Mumberg et al., 1991; Schuermann et al., 1991; Yen et al., 1991; Wisdom et al., 1992). Indeed, $\Delta$-FosB antagonizes the transforming activity of Fos and FosB in some instances (Mumberg et al., 1991; Yen et al., 1991). In transactivation assays, both Fos and FosB stimulate transcription from AP-1 sites, whereas $\Delta$-FosB either has reduced activity (Dobrzanski et al., 1991) or actually represses the activity of other Fos family members (Mumberg et al., 1991; Nakabeppu and Nathans, 1991; Yen et al., 1991). The attenuation is presumed to occur through binding of $\Delta$-FosB to Jun family members and occupation of the AP-1 site, where it does not provide a strong transactivation signal. Thus, $\Delta$-FosB-containing complexes compete effectively for binding with more active AP-1 complexes at AP-1 sites. Therefore, the chronic expression of the $37 \mathrm{kDa}$ $\Delta$-FosB could antagonize the actions of transiently induced AP-1 complexes (principally Fos-JunB) generated during subsequent periods of intense neuronal activation. For example, it might suppress basal and activated expression of AP-1-dependent genes that are involved in neuronal sprouting. However, the transactivation potential of the $37 \mathrm{kDa}$ form of $\Delta$-FosB has not been determined formally. In addition, $\Delta$-FosB has positive transactivating activity in fibroblasts (Dobrzanski et al., 1991) and could, therefore, upregulate genes in the nervous system. These various possibilities can be addressed in wild-type and fosB-null mice.

Kainic acid triggers seizures and leads to neuronal damage and death. Therefore, it will be important to establish whether fos $\mathrm{B}$ has any association with neuropathophysiological processes in humans. Moreover, the fos B-null mice provide a model with which to elucidate the molecular and cellular mechanisms that contribute to the genesis of the epileptic state.

\section{REFERENCES}

Angel P, Baumann I, Stein B, Delius H, Rahmsdorf HJ, Herrlich P (1987) 12-O-Tetradecanoyl-phorbol-13-acetate induction of the human collaenase gene is mediated by an inducible enhancer element located in the $5^{\prime}$-flanking regions. Mol Cell Biol 7:2256-2266.

Bendotti C, Vezzani A, Tarizzo G, Samanin R (1993) Increased expression of GAP-43, somatostatin and neuropeptide Y mRNA in the hippocampus during development of hippocampal kindling in rats. Eur J Neurosci 5:1312-1320.

Bengzon J, Kokaia Z, Ernfors P, Kokaia M, Leanza G, Nilsson OG, Persson H, Lindvall O (1993) Regulation of neurotrophin and trkA and trkC tyrosine kinase receptor messenger RNA expression in kindling. Neuroscience 53:433-436.

Brown JR, Ye H, Bronson RT, Dikkes P, Greenberg ME (1996) A defect in nurturing in mice lacking the immediate early gene fos B. Cell 86:297-309.

Chen J, Nye HE, Kelz MB, Hiroi N, Nakabeppu Y, Hope BT, Nestler EJ (1995) Regulation of $\Delta$ FosB and FosB-like proteins by electroconvulsive seizure and cocaine treatments. Mol Pharmacol 48:880-889.

Curran T, Franza Jr BR (1988) Fos and Jun: the AP-1 connection. Cell 55:395-397.

Curran T, Morgan JI (1987) Memories of Fos. BioEssays 7:255-258.

Dobrzanski P, Noguchi T, Kovary K, Rizzo CA, Lazo PS, Bravo R (1991) Both products of the fos B gene, FosB and its short form, FosB/SF, are transcriptional activators in fibroblasts. Mol Cell Biol 11:5470-5478.
Ernfors P, Bengzon J, Kokaia Z, Persson H, Lindvall O (1991) Increased levels of messenger RNAs for neurotrophic factors in the brain during kindling epileptogenesis. Neuron 7:165-176.

Gall CM, Isackson PJ (1989) Limbic seizures increase neuronal production of messenger RNA for nerve growth factor. Science 245:758-761.

Gall CM, Murray K, Isackson PJ (1991) Kainic acid-induced seizures stimulate increased expression of nerve growth factor mRNA in rat hippocampus. Mol Brain Res 9:113-123.

Gruda MC, van Amsterdam J, Rizzo CA, Durham SK, Lira S, Bravo R (1996) Expression of FosB during mouse development: normal development of FosB knockout mice. Oncogene 12:2177-2185.

Herdegen T, Fiallos-Estrada CE, Schmid W, Bravo R, Zimmerman M (1992) The transcription factors c-Jun, Jun D and CREB proteins, but not Fos and KROX-24, are differentially regulated in axotomized neurons following transection of rat sciatic nerve. Mol Brain Res 14:155-165.

Hope BT, Kosofsky B, Hyman SE, Nestler EJ (1992) Regulation of immediate early gene expression and AP-1 binding in the rat nucleus accumbens by chronic cocaine. Proc Natl Acad Sci USA 89:5764-5768.

Hope BT, Kelz MB, Duman RS, Nestler EJ (1994a) Chronic electroconvulsive seizure (ECS) treatment results in expression of a longlasting AP-1 complex in brain with altered composition and characteristics. J Neurosci 14:4318-4328.

Hope BT, Nye HE, Kelz MB, Self DW, Iadarola M, Nakabeppu Y, Duman RS, Nestler EJ (1994b) Induction of a long-lasting AP-1 complex composed of altered Fos-like proteins in brain by chronic cocaine and other chronic treatments. Neuron 13:1235-1244.

Isackson PJ, Huntsman MM, Murray KD, Gall CM (1991) BDNF mRNA expression is increased in adult rat forebrain after limbic seizures: temporal patterns of induction distinct from NGF. Neuron 6:937-948.

Jenkins R, Hunt SP (1991) Long-term increase in the levels of c-jun mRNA and Jun protein-like immunoreactivity in motor and sensory neurons following axon damage. Neurosci Lett 129:107-110.

Kaminska B, Filipkowski RK, Zurkowska G, Lason W, Przewlocki R, Kaczmarek L (1994) Dynamic changes in the composition of the AP-1 transcription factor DNA-binding activity in the rat brain following kainate-induced seizures and cell death. Eur J Neurosci 6:1558-1566.

Kasof GM, Mandelzys A, Maika SD, Hammer RE, Curran T, Morgan JI (1995) Kainic acid-induced neuronal death is associated with DNA damage and a unique immediate-early gene response in c-fos-lac Z transgenic rats. J Neurosci 15:4238-4249.

Kerr LD, Holt JT, Matrisian LM (1988) Growth factors regulate transin gene expression by c-fos-dependent and c-fos-independent pathways. Science 242:1424-1427.

Kovary K, Bravo R (1991) Expression of different Jun and Fos proteins during the G0-G1 transition in mouse fibroblasts: in vitro and in vivo associations. Mol Cell Biol 11:2451-2459.

Kovary K, Rizzo CA, Ryseck RP, Noguchi T, Raynoschek C, Pelosin JM, Bravo R (1991) Constitutive expression of FosB and its short form, FosB/SF, induces malignant cell transformation in rat-1A cells. New Biol 3:870-879.

Meberg PJ, Gall CM, Routtenberg A (1993) Induction of F1/GAP-43 gene: expression in hippocampal granule cells after seizures. Mol Brain Res 17:295-297.

Morgan JI, Curran T (1986) The role of ion flux in the control of c-fos expression. Nature 322:552-555.

Morgan JI, Curran T (1991a) Stimulus-transcription coupling in the nervous system: involvement of the inducible proto-oncogenes fos and jun. Annu Rev Neurosci 14:421-451.

Morgan JI, Curran T (1991b) Proto-oncogene transcription factors and epilepsy. Trends Pharmacol Sci 12:343-349.

Morgan JI, Cohen DR, Hempstead JL, Curran T (1987) Mapping patterns of c-fos expression in the central nervous system after seizure. Science 237:192-197.

Mumberg D, Lucibello FC, Schuermann M, Muller R (1991) Alternative splicing of fos B transcripts results in differentially expressed mRNAs encoding functionally antagonistic proteins. Genes Dev 5:1212-1223.

Nakabeppu Y, Nathans D (1991) A naturally occurring truncated form of FosB that inhibits Fos/Jun transcriptional activity. Cell 64:751-759.

Nedivi E, Basi GS, Akey IV, Skene JH (1992) A neural specific GAP-43 core promoter located between unusual DNA elements that interact to regulate its activity. J Neurosci 12:691-704.

Pennypacker KR, Thai L, Hong J-S, McMillian MK (1994) Prolonged 
expression of AP-1 transcription factors in the rat hippocampus after systemic kainate treatment. J Neurosci 14:3998-4006.

Pennypacker KR, Hong J-S, McMillan MK (1995) Implications of prolonged expression of Fos-related antigens. Trends Pharmacol Sci 16: 317-321.

Rudge JS, Pasnikowski EM, Holst P, Lindsay RM (1995) Changes in neurotrophic factor expression and receptor activation following exposure of hippocampal neuron/astrocyte cocultures to kainic acid. J Neurosci 15:6856-6867.

Schonthal A, Herrlich P, Rahmsdorf HJ, Ponta H (1988) Requirement for fos gene expression in the transcriptional activation of collagenase by other oncogenes and phorbol esters. Cell 54:325-334.

Schuermann M, Jooss K, Muller R (1991) fos B is a transforming gene encoding a transcriptional activator. Oncogene 6:567-576.

Sheng M, Greenberg ME (1990) The regulation and function of c-fos and other immediate-early genes in the nervous system. Neuron 4:477485 .

Simmons DM, Arriza JL, Swanson LW (1989) A complete protocol for in situ hybridization of messenger RNAs in brain and other tissues with radiolabeled single-stranded RNA probes. J Histotechnol 12:169-181.

Sonnenberg JL, Macgregor-Leon PF, Curran T, Morgan JI (1989) Dynamic alterations occur in the levels and composition of transcription factor AP-1 complexes after seizure. Neuron 3:359-365.

Watanabe Y, Johnson RS, Butler LS, Binder DK, Spiegelman BM,
Papaioannou VE, McNamara JO (1996) Null mutation of c-fos impairs structural and functional plasticities in the kindling model of epilepsy. J Neurosci 16:3827-3836.

Winston SM, Hayward MD, Nestler EJ, Duman RS (1990) Chronic electroconvulsive seizures down-regulate expression of the immediateearly genes c-fos and c-jun in rat cerebral cortex. J Neurochem 54:1920-1925.

Wisdom R, Yen J, Rashid D, Verma IM (1992) Transformation by FosB requires a trans-activation domain missing in FosB2 that can be substituted by heterologous activation domains. Genes Dev 6:667-675.

Yen J, Wisdom RM, Tratner I, Verma IM (1991) An alternative spliced form of FosB is a negative regulator of transcriptional activation and transformation by Fos proteins. Proc Natl Acad Sci USA 88:5077-5081.

Young S, Porrino LJ, Iadarola MJ (1991) Cocaine induces striatal c-Fos immunoreactive proteins via dopaminergic D1 receptors. Proc Natl Acad Sci USA 88:1291-1295.

Zafra F, Hengerer B, Leibrock J, Thoenen H (1990) Activity dependent regulation of BDNF and NGF mRNAs in the rat hippocampus is mediated by non-NMDA glutamate receptors. EMBO J 9:3545-3550.

Zerial M, Toschi L, Ryseck R-P, Schuermann M, Muller R, Bravo R (1989) The product of a novel growth factor activated gene, fosB, interacts with Jun proteins enhancing their DNA binding activity. EMBO J 8:805-813. 